\title{
Pengaruh Lingkungan Kerja Terhadap Semangat Dan Kegairahan Kerja Karyawan Pada Kantor Administrator
}

\author{
Siti Nur Azisyah Satria*1 \\ A. Kartini sari putri $\mathbf{D}^{2}$ \\ Mariam Makmur ${ }^{3}$ \\ 1,2,3 Manajemen, Sekolah Tinggi Ilmu Ekonomi Ichsan Sidenreng Rappang, Indonesia \\ *e-mail: stnurazisyah@gmail.com ${ }^{1}$, aksputrid@gmail.com² Mariammakmur@gmail.com $^{3}$
}

(Naskah masuk : tgl bln thn, Revisi : 1922 2021, Publikasi : 1201 2022)

\begin{abstract}
Abstrak
Masalah yang timbul disini yang lebih terletak pada karyawan itu sendiri. Dengan kata lain, cara tersebut belum menjamin bahwa para karyawan akan bekerja dengan sepenuh hati. Upaya dapat meningkatkan produktifitas lebih tinggi lagi, perusahaan perlu menumbuhkan semangat kegairahan kerja dari para karyawan. Sudah selayaknyalah apabila perusahaan akan selalu berusaha agar para karyawan mempunyai semangat dan kegairahan kerja yang tinggi. Penelitian ini bertujuan untuk mengetahui pengaruh lingkungan kerja terhadap semangat dan kegairahan kerja studi pada karyawan kantor administrator. Dalam penelitian ini Laporan penelitian disusun dan diselesaikan dengan pedoman pada metode kasus, yaitu suatu metode bermaksud menerangkan obyekyang diteliti dengan mempergunakan data dari obyek yang diteliti itu sendiri. Populasi dalam penelitian ini adalah seluruh karyawan pada Kantor Administrator Pelabuhan Makassar. Jumlah sampel dalam penelitian ini ditentukan sebanyak 60 orang. Hasil penelitian menemukan bahwa responden karyawan Kantor Administrator Pelabuhan Makassar menunjukkan sebagian besar responden merasa setuju atau puas bahwa Lingkungan Kerja berpengaruh positif terhadap Semangat dan Kegairahan Kerja karyawan pada Kantor Administrator Pelabuhan Makassar. Ini terlihat adanya jawaban responden sangat puas sebanyak $64,5 \%$.
\end{abstract}

Kata kunci: kegairahan kerja karyawan, lingkungan kerja, semangat

\begin{abstract}
The problem that arises here lies in the employees themselves. In other words, this method does not guarantee that employees will work wholeheartedly. Efforts to increase productivity even higher, companies need to foster a spirit of enthusiasm for work from employees. It is appropriate if the company will always try so that employees have high enthusiasm and enthusiasm for work. This study aims to determine the effect of the work environment on the enthusiasm and enthusiasm of the study work in the administrator's office employees. In this study, the research report was compiled and completed with guidelines on the case method, which is a method intended to explain the object under study using data from the object under study itself. The population in this study were all employees at the Makassar Port Administrator Office. The number of samples in this study was determined as many as 60 people. The results of the study found that the respondents of Makassar Port Administrator Office employees indicated that most of the respondents agreed or satisfied that the work environment had a positive effect on the enthusiasm and enthusiasm of employees at the Makassar Port Administrator Office. It can be seen that the respondents' answers are very satisfied as much as $64.5 \%$.
\end{abstract}

Keywords: enthusiasm, enthusiasm for employee work, work environment

\section{PENDAHULUAN}

Setiap perusahaan akan selalu berusaha agar produktivitas kerja para karyawannya dapat terus ditingkatkan. Penyelidikan waktu dan gerak dari para karyawannya sangat diperlukan. Mempelajari gerak-gerik yang tidak diperlukan dan melelahkan serta tidak efesien sehingga dapat diciptakan gerak-gerik baru yang lebih efektif dan dapat mengurangi kelelahan serta mempercepat pekerjaan. Kegiatan ini dikenal dengan studi waktu dan gerak.

Cara ini memang pekerjaan dapat dipercepat dan kelelahan dapat dikurangi, tetapi masih ada masalah yang timbul disini yang lebih terletak pada karyawan itu sendiri. Dengan kata lain, cara tersebut belum menjamin bahwa para karyawan akan bekerja dengan sepenuh hati. Upaya dapat meningkatkan produktifitas lebih tinggi lagi, perusahaan perlu menumbuhkan semangat 
kegairahan kerja dari para karyawan. Sudah selayaknyalah apabila perusahaan akan selalu berusaha agar para karyawan mempunyai semangat dan kegairahan kerja yang tinggi.

Dapatlah dikatakan, semangat dan kegairahan kerja dapat mempertinggi produktivitas dalam kondisi tertentu, akan tetapi pada kondisi lain ternyata tidak begitu berpengaruh terhadap produltivitas seperti pada semua pekerjaan yang dilakukan dengan mesin. Faktor lain yang juga berpengaruh pada semangat dan kegairahan kerja yaitu lingkungan kerja. Meskipun faktor ini penting dan besar pengaruhnya, tapi banyak perusahaan yang sampai saat ini kurang memperhatikan faktor ini. Misalnya soal musik yang merdu, meskipun kelihatannya remeh, tetapi besar pengaruhnya terhadap efektivitas dan efesien dalam pelaksanaan tugas karena musik dapat mengurangi kelelahan dari para karyawannya.

Berdasarkan penjelasan di atas maka dapatlah dimengerti bahwa lingkungan kerja bukan hanya sekedar berpengaruh terhadap semangat dan kegairahan kerja dalam pelaksanaan tugas, tetapi seringkali pengaruhnya cukup besar. Karena faktor-faktor tersebut di atas termasuk lingkungan kerja dan ternyata dapat berpengaruh terhadap pekerjaan yang dilakukan, maka setiap perusahaan haruslah mengusahakan agar faktor-faktor yang termasuk lingkungan kerja diusahakan sedemikian rupa sehingga mempunyai pengaruh positif.

Adapun yang menjadi masalah pokok sehubungan latar belakang masalah adalah : “ Bagaimanakah pengaruh lingkungan kerja terhadap semangat dan kegairahan kerja karyawan pada Kantor Administrator Pelabuhan Makassar? “.

\section{Tujuan Penelitian}

a. Untuk mengetahui pengaruh lingkungan kerja terhadap semangat dan kegairahan kerja pegawai atau karyawan

b. Untuk mengetahui bahwa dalam bekerja dibutuhkan suasana yang menyenangkan dan lingkungan kerja kantor yang memadai merupakan suatu hal yang penting bagi seorang pegawai atau karyawan.

Menurut Edwin B. Flippo (Sedarmayanti, 2001:5) manajemen sumber daya manusia adalah perencanaan, pengoganisasian, pengarahan, dan pengawasan kegiatan-kegiatan, pengadaan, pengembangan, pemberian kompensasi, pengintegrasian, pemeliharaan dan pelepasan sumber daya manusia agar tercapai tujuan individu, organisasi dan masyarakat. Sedangkan menurut French (Sedarmanti, 2001 : 5) manajemen sumber daya manusia adalah sebagai penarikan, seleksi, pengembangan, penggunaan, dan pemeliharaan sumber daya manusia dan organisasi.

Pengertian Lingkungan Kerja menurut Alex S. Nitisemito (1997 : 183) lingkungan kerja adalah segala sesuatu yang ada disekitar para pekerja atau pegawai dan yang dapat mempengaruhi dirinya dalam menjalankan tugas atau pekerjaan yang dibebankan. Untuk lebih memahami pengertian dari motivasi, antara lain dikemukakan oleh Handoko (2000:252) sebagai berikut :" Motivasi adalah keadaan dalam diri seseorang yang mendorong keinginan individu untuk melakukan kegiatan-kegiatan tertentu guna mencapai tujuan tertentu "

Pengertian semangat kerja dan kegairahan kerja menurur Alex S. Nitisemito (1997: 180) Semangat kerja adalah melakukan pekerjaan secara lebih sehingga dengan demikian pekerjaan akan dapat diharapkan lebih cepat lebih baik. Sedangkan kegairahan kerja adalah kesenangan yang mendalam terhadap pekerjaan yang dilakukan.

Adapun kegairahan kerja menurut Guba (Mutiara S. Panggabean, 2004 : 21) semangat kerja adalah pemilikan atau kebersamaan. Semangat kerja merujuk kepada adanya kebersamaan. Hal ini merupakan rasa pemahaman dengan perhatian terhadap unsur-unsur dari pekerjaan seseorang, kondisi kerja, rekan kerja, penyelia, pimpinan dan perusahaan. Semangat dan kegairahan kerja sebenarnya banyak bergantung kepada hubungan antara pengharapan dan realitas. Semakin kongkrit lingkungan kerja tempat para karyawan bekerja memberi pengharapan akan adanya peningkatan bagi diri tenaga kerja, maka semangat dan kegairahan kerja tersebut diharapkan akan semakin meningkat. Demikian pula sebaliknya, semakin tidak jelas lingkungan kerja dalam memberi pengharapan akan adanya peningkatan diri tenaga kerja, maka semangat dan kegairahan tanpa melalui kompromi akan merosot, walaupun kurang diduga manajemen sebelumnya. 
Karyawan adalah aset utama perusahaan yang menjadi perencana dan pelaku aktif dari setiap aktivitas organisasi. Karyawan yang cakap, mampu, dan terampil belum menjamin efisiensi kerja yang baik, kalau moral kerja dan kedisiplinannya rendah. Mereka baru bermanfaat dan mendukung terwujudnya tujuan perusahaan, jika mereka berkeinginan berprestasi.

\section{Kerangka Pikir}

Kantor Administrator Pelabuhan Makassar dalam usahanya untuk meningkatkan produktifitas kerja perusahaan menganalisa lebih jauh serta meningkatkan dan memperbaiki kualitas faktor-faktor yang berhubungan dengan lingkungan kerja yang tentunya akan berpengaruh terhadap semangat dan kegairahan karyawan. Dengan meningkatkan kegairahan dan semangat karyawan dalam bekerja maka akan berpengaruh terhadap peningkatan probuktifitas kerja karyawan yang ada pada kantor Administrator Pelabuhan Makassar.

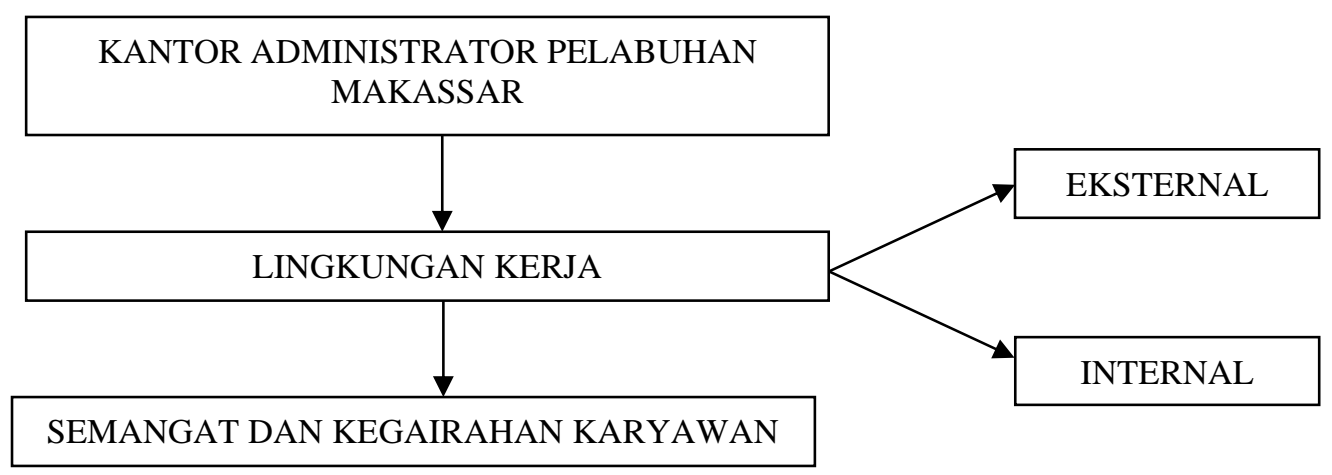

Gambar 1. Kerangka Pikir

Berdasarkan masalah dan tujuan penelitian maka hipotesis yang diajukan dalam penelitian adalah : " Diduga bahwa lingkungan kerja berpengaruh positif terhadap semangat dan kegairahan kerja karyawan.

\section{METODE}

Adapun perusahaan yang akan dijadikan obyek penelitian adalah Kantor Administrator Pelabuhan Makassar yang bertempat di Jalan Hatta No.2 Makassar. Penelitian dan penulisan sampai pada penyusunan laporan kurang lebih 2 (dua) bulan. Penelitian ini bertujuan untuk mengetahui pengaruh lingkungan kerja terhadap semangat dan kegairahan kerja studi pada karyawan kantor administrator. Dalam penelitian ini Laporan penelitian disusun dan diselesaikan dengan pedoman pada metode kasus, yaitu suatu metode bermaksud menerangkan obyek yang diteliti dengan mempergunakan data dari obyek yang diteliti itu sendiri.

Populasi dalam penelitian ini adalah seluruh karyawan pada Kantor Administrator Pelabuhan Makassar. Jumlah sampel dalam penelitian ini ditentukan sebanyak 60 orang. dalam penelitian ini adalah metode Accidental Sampling, yaitu sampel dipilih dengan cara memilih siapa saja yang ditemui saat itu, dalam hal ini adalah karyawan yang ditemui saat itu untuk menjawab kuisioner. analisis data yang digunakan untuk menguji untuk hipotesis yang telah diajukan dalam penelitian ini adalah metode Deskriptif Kualitatif dengan menggunakan kuisioner. Acuan pengukuran untuk mengukur tingkat kepuasan karyawan digunakan skala 5 tingkat (likert) dimana skala likert merupakan metode untuk pemberian ranking dan scoring ada kejadian, objek dan lain-lain secara relatif yang terdiri atas: Sangat Puas, Puas, cukup Puas, Tidak Puas, Sanga Tidak Puas.

Tabel 1. Penilaian Score Pernyataan

\begin{tabular}{ccc}
\hline Jenis Pernyataan & Jenis Jawaban & Score \\
\hline \multirow{4}{*}{ Positif } & Sangat Tidak Setuju (STS) & 1 \\
& Tidak Setuju (TS) & 2 \\
& Ragu-ragu (R) & 3 \\
& Setuju (S) & 4 \\
& Sangat Setuju (SS) & 5 \\
\hline
\end{tabular}




\section{Metode Pengumpulan Data}

1. Jenis Data

Dalam penelitian ini, jenis data yang digunakan adalah data kuantitatif. Data kuantitatif menurut Mudrajad kuncoro $(2009 ; 145)$ ialah data yang diukur dalam suatu skala numeric (angka)

2. Sumber Data

a. Data Primer

Data primer adalah data yang diperoleh secara langsung dari sumber asli (tanpa perantara). Data primer yang ada dalam penelitian ini merupakan hasil penyebaran kuesioner pada sampel yang telah ditentukan.

Dari kuesioner tersebut akan didapat data mengenai bagaimana tanggapan responden mengenai variable-variabel yang ada dalam penelitian ini yaitu variable pengaruh lingkungan kerja(X1), sebagai factor- semangat (Y1) dan kegairahan kerja karyawan (Y2).

b. Data Sekunder

Data sekunder adalah data yang diperoleh secara tidak langsung (ada perantara). Baik berupa keterangan maupun litelatur yang ada hubungannya dengan penelitian ini. Data yang digunakan dalam penelitian ini adalah data yang bersumber dari jurnal, artikel, internet, dan surat kabar, dan lain-lain.

3. Teknik Pengumpulan data

Teknik pengumpulan data yang dilakukan dalam penelitian ini adalah:

a. Penelitian lapangan (Field Research), Kuesioner merupakan teknik pengumpulan data yang dilakukan dengan cara menyusun pertanyaan-pertanyaan yang terdiri dari antara lain seputar data diri responden dimana dalam hal ini menggunakan skala nominal (nominal scale) yang menghasilkan jawaban berupa nama atau tanda dari sesuatu. Skala yang digunakan adalah skala interval (Interval Scale) yang dapat menghasilkan data yang memiliki rentang nilai dan menghasilkan pengukuran yang memungkinkan perhitungan statistik yang diperlukan saat pengolahan data.

b. Studi Kepustakaan

Merupakan pengumpulan data dengan tujuan untuk mengetahui berbagai pengetahuan atau teori-teori yang berhubungan dengan permasalahan penelitian, diantaranya berasal dari buku, majalah, jurnal, maupun berbagi litelatur yang relevan dengan penelitian ini.

\section{Uji Asumsi Klasik}

\section{Uji Normalitas}

Uji normalitas bertujuan untuk menguji apakah dalam model regresi, variabel pengganggu atau residual memiliki distribusi normal. Seperti diketahui bahwa uji t mengasumsikan bahwa nilai residual mengikuti distribusi normal. Kalau asumsi ini dilanggar maka uji statistik menjadi tidak valid untuk jumlah sampel kecil (Ghozali, 2011).

Uji normalitas yang digunakan dalam penelitian ini adalah uji statistik One Sample Kolmogorov-Smirnov Test. Dalam uji One Sample Kolmogorov-Smirnov Test, variabel-variabel yang mempunyai Asymp. Sig (2-tailed) di bawah tingkat signifikan sebesar 0,05 (probabilitas < 0,05 ) diartikan bahwa variabel-variabel tersebut memiliki distribusi tidak normal. Sebaliknya jika variabel-variabel yang mempunyai Asymp. Sig (2-tailed) di atas tingkat signifikan sebesar 0,05 (probabilitas $>0,05$ ) diartikan bahwa variabel-variabel tersebut memiliki distribusi normal.

2. Uji Multikolinieritas

Uji Multikolonieritas bertujuan untuk menguji apakah model regresi ditemukan adanya korelasi antar variabel bebas (independen). Model regresi yang baik seharusnya tidak terjadi korelasi diantara variabel independen. Jika variabel independen saling berkorelasi, maka variabel-variabel tidak ortogonal. Variabel ortogonal adalah variabel independen yang nilai korelasi antar sesama variabel independen sama dengan nol (Ghozali, 2011). Untuk mendeteksi bahwa ada tidaknya multikolinieritas di dalam regresi dapat dilihat dari: (1) tolerance value, (2) nilai variance inflation factor (VIF). Model regresi yang bebas multikolinieritas adalah yang 
mempunyai tolerance value di atas 0,1 atau VIF di bawah 10 (Ghozali, 2011). Apabila tolerance variance di bawah 0,1 atau VIF di atas 10 maka terjadi multikolinieritas.

3. Uji Heterokedastisitas

Uji Heteroskedastisitas bertujuan menguji apakah dalam model regresi terjadi ketidaksamaan variance dari residual satu pengamatan ke pengamatan lain. Jika variance dari residual satu pengamatan ke pengamatan lain tetap, maka disebut Homoskedastisitas dan jika berbeda disebut Heteroskedastisitas. Model regresi yang baik adalah yang Homoskedastisitas atau tidak terjadi Heteroskedastisitas (Ghozali, 2011).

Uji yang digunakan dalam penelitian ini adalah uji Glejser. Uji ini dilakukan dengan meregresi nilai absolut residual terhadap variabel independen. Jika variabel independen secara statistik berpengaruh signifikan terhadap variabel dependen maka terdapat indikasi terjadi Heteroskedastisitas dalam model regresi yang digunakan. Jika tidak ada satu pun variabel independen yang secara statistik berpengaruh signifikan terhadap variabel dependen maka tidak terjadi heteroskedastisitas dalam model regresi yang digunakan (Ghozali, 2011).

\section{Metode Analisis}

Dalam penelitian ini mempunyai tujuan untuk melihat pengaruh hubungan antara variabel independen terhadap variabel dependen dengan menggunakan analisis regresi linier berganda yang akan diolah menggunakan SPSS. Teknik analisis regresi linier berganda digunakan untuk mengetahui pengaruh variabel bebas (lingkungan kerja terhadap semangat kerja dan kegairahan kerja) secara parsial. Data yang dikumpulkan dalam penelitian ini diolah dan kemudian dianalisis dengan berbagai uji statistik sebagai berikut:

1. Analisis Statistik Deskriptif

Analisis statistik deskriptif memberikan gambaran atau deskripsi suatu data yang dilihat dari nilai rata-rata (mean), standar deviasi, varian, maksimum, minimum, sum, range, kurtosis, dan skewness (kemencengan distribusi). Hal ini perlu dilakukan untuk melihat gambaran keseluruhan dari sampel yang berhasil dikumpulkan dan memenuhi syarat untuk dijadikan sampel penelitian.

\section{Uji Hipotesis}

Hipotesis dalam penelitian ini yaitu lingkungan kerja terhadap semangat kerja dan kegairahaan kerja. Pengujian hipotesis menggunakan analisis regresi berganda. Analisis regresi berganda dapat diukur dari nilai koefisien determinasi, dan nilai stastistik $\mathrm{t}$.

1. Uji Koefisien Determinasi $\left(\mathrm{R}^{2}\right)$

Koefisien determinasi $\left(\mathrm{R}^{2}\right)$ mengukur seberapa jauh kemampuan model regresi dalam menerangkan variasi variabel dependen. Nilai koefisien determinasi adalah antara nol dan satu. Nilai $\mathrm{R}^{2}$ yang kecil berarti kemampuan variable variabel independen dalam menjelaskan variasi variabel dependen amat terbatas. Nilai yang mendekati satu berarti variabel-variabel independen memberikan hampir semua informasi yang dibutuhkan untuk memprediksi variasi variabel dependen.

Kelemahan mendasar penggunaan koefisien determinasi adalah bias terhadap jumlah variabel independen yang dimasukkan ke dalam model. Setiap tambahan satu variabel independen, maka $R^{2}$ pasti meningkat. Oleh karena itu, banyak peneliti menganjurkan untuk menggunakan nilai Adjusted $\mathrm{R}^{2}$ pada saat mengevaluasi mana model regresi terbaik. Tidak seperti $\mathrm{R}^{2}$, nilai Adjusted $\mathrm{R}^{2}$ dapat naik atau turun apabila satu variabel independen ditambahkan ke dalam model regresi.

2. Uji Parsial (Uji t)

Pengujian koefisien secara parsial adalah untuk mengetahui pengaruh masing-masing variabel independen secara parsial (sendiri) terhadap variabel dependennya. Proses pengujian menggunakan uji t (t-test), dengan rumus:

$$
t=\frac{\beta_{i}}{\operatorname{Se}(\beta i)}
$$

Selanjutnya untuk mengetahui apakah variabel independen (secara parsial) mempunyai pengaruh negatif secara nyata (signifikan) terhadap variabel dependen dilakukan dengan 
membandingkan nilai $t_{\text {hitung }}$ dengan nilai $t_{\text {tabel }}$ pada tingkat signifikan $(\alpha)$ dan derajat kebebasan (df) tertentu $(\mathrm{df}=\mathrm{n}-\mathrm{k}-1)$. dengan ktriteria pengujian sebaga berikut:

- Jika $-\mathrm{t}_{\text {tabel }} \leq \mathrm{t}_{\text {hitung, }}$ maka $\mathrm{H}_{0}$ diterima dan $\mathrm{H}_{\mathrm{a}}$ ditolak (Uji pihak kiri)

- Jika $t_{\text {tabel }} \geq t_{\text {hitung, }}$ maka $\mathrm{H}_{0}$ diterima dan $\mathrm{H}_{\mathrm{a}}$ ditolak (Uji pihak kanan)

Bila $\mathrm{H}_{0}$ diterima maka dapat disimpulkan suatu yang berpengaruh tidak signifikan, sedangkan bila $\mathrm{H}_{0}$ ditolak artinya suatu berpengaruh signifikan.

\section{HASIL DAN PEMBAHASAN}

Bagian hasil penelitian memuat hasil analisis uji hipotesis yang dapat menyertakan tabel, grafik, Klasifikasi responden berdasarkan umur karyawan pada Kantor Administrator.

Tabel 2. Pelabuhan Makassar

\begin{tabular}{ccc}
\hline Umur (thn) & Jumlah Responden & Presentase (\%) \\
\hline 24 & 10 & 16,2 \\
25 & 8 & 12,9 \\
28 & 12 & 19,4 \\
30 & 8 & 12,9 \\
31 & 9 & 14,5 \\
32 & 5 & 8,1 \\
33 & 3 & 4,8 \\
34 & 3 & 4,8 \\
35 & 2 & 3,2 \\
43 & 2 & 3,2 \\
Jumlah & 62 & 100 \\
\hline
\end{tabular}

Sumber: Hasil pengolahan data 2021

Dari tabel 2 diatas dapat dilihat bahwa dari hasil 62 kuisioner yang diedarkan pada responden karyawan Kantor Administrator Pelabuhan Makassar berdasarkan umur, yaitu responden umur 28 tahun merupakan responden dengan presentase 19,4\%.

Tabel 3. Klasifikasi responden berdasarkan jenis kelamin karyawan pada Kantor Administrator Pelabuhan Makassar

\begin{tabular}{ccc}
\hline Umur (thn) & Jumlah Responden & Presentase (\%) \\
\hline Laki-laki & 45 & 72,6 \\
Perempuan & 17 & 27,4 \\
Jumlah & 62 & 100 \\
\hline
\end{tabular}

Sumber: Hasil pengolahan data 2021

Dari tabel 3 diatas dapat dilihat bahwa dari hasil 62 kuisioner yang diedarkan pada responden karyawan pada Kantor Adminisrator Pelabuhan Makassar berdasarkan jenis kelamin, yaitu dari jenis kelamin laki-laki jumlah responden 45 orang atau $72,6 \%$ dan jenis kelamin perempuan jumlah responden 17 orang atau $27,4 \%$.

Dari tabel 4 dapat dilihat bahwa dari hasil 62 kuisioner yang diedarkan pada responden karyawan pada Kantor Administrator Pelabuhan Makassar berdasarkan status perkawinan, yaitu dari status yang sudah menikah jumlah responden 32 orang atau $51,6 \%$ dan status yang belum menikah jumlah responden 30 orang atau $48,4 \%$.

Tabel 4. Klasifikasi responden berdasarkan status perkawinan pada karyawan pada Kantor Administrator Pelabuhan Makassar

\begin{tabular}{ccc}
\hline Umur (thn) & Jumlah Responden & Presentase (\%) \\
\hline Menikah & 32 & 51,6 \\
Belum Menikah & 30 & 48,4 \\
Jumlah & 62 & 100 \\
\hline
\end{tabular}


Tabel 5. Klasifikasi responden berdasarkan latar belakang pendidikan terakhi (umum) karyawan pada kantor Administrator Pelabuhan Makassar

\begin{tabular}{ccc}
\hline $\begin{array}{c}\text { Latar Belakang } \\
\text { Pendidikan }\end{array}$ & $\begin{array}{c}\text { Jumlah } \\
\text { Responden }\end{array}$ & Presentase (\%) \\
\hline SD & - & - \\
SLTA & - & - \\
SLTA & 15 & 24,2 \\
DIPLOMA & 22 & 35,5 \\
S - 1 & 25 & 40,3 \\
S - 2 & - & - \\
Jumlah & 62 & 100 \\
\hline
\end{tabular}

Sumber: Hasil pengolahan data 2021

Dari tabel 5 diatas dapat dilihat bahwa dari hasil 62 kuisioner yang diedarkan pada responden karyawan pada Kantor Administrator Pelabuhan Makassar berdasarkan latar belakang pendidikan terakhir (umum), yaitu latar belakang SD jumlah responden 0 atau $0 \%$, latar belakang pendidikan SLTP jumlah responden 0 atau 0\%, latar belakang pendidikan SLTA jumlah responden 15 orang atau 24,2\%, latar belakang Diploma jumlah responden 22 orang atau 35,5\%, latar belakang pendidikan S-1 jumlah responden 25 orang atau 40,3\%, dan latar belakang S-2 jumlah responden 0 atau $0 \%$. Melihat besarnya sampel dari latar belakang pendidikan $\mathrm{S}-1$ menyatakan bahwa hasil kuisioner diharapkan dapat dijawab secara rasional.

Tabel 6. Klasifikasi responden berdasarkan karyawan lama bekerja (tahun) pada Kantor Administrator Pelabuhan Makassar

\begin{tabular}{ccc}
\hline $\begin{array}{c}\text { Lama Bekerja } \\
\text { (thn) }\end{array}$ & $\begin{array}{c}\text { Jumlah } \\
\text { Responden }\end{array}$ & Persentase (\%) \\
\hline 2 thn & 5 & 8,1 \\
3 thn & 5 & 8,1 \\
4 thn & 8 & 12,9 \\
5 thn & 9 & 14,5 \\
6 thn & 9 & 14,5 \\
7 thn & 10 & 16,1 \\
10 thn & 8 & 12,9 \\
15 thn & 8 & 12,9 \\
Jumlah & 62 & 100 \\
\hline
\end{tabular}

Dari tabel 6 diatas dapat dilihat bahwa dari hasil 62 kuisioner yang diedarkan pada responden karyawan pada Kantor Administrator Pelabuhan Makassar berdasarkan karyawan yang lama bekerja pada instansi yaitu responden terbanyak adalah karyawan yang bekerja lebih dari 7 tahun. Meskipun yang terbanyak adalah karyawan yang lama bekerja 7 tahun dapat diartikan bahwa mereka telah mempunyai pengalaman dalam perusahaan.

Tabel 7. Klasifikasi responden berdasarkan Lingkungan Kerja pada Kantor Administrator Pelabuhan Makassar

\begin{tabular}{ccc}
\hline $\begin{array}{c}\text { Jawaban } \\
\text { Responden }\end{array}$ & $\begin{array}{c}\text { Jumlah } \\
\text { Responden }\end{array}$ & Presentase (\%) \\
\hline Sangat Puas & 40 & 64,5 \\
Puas & 17 & 27,4 \\
Cukup Puas & 5 & 8,1 \\
Tidak Puas & - & - \\
Sangat Tidak Puas & - & - \\
Jumlah & 62 & 100 \\
\hline
\end{tabular}


Tabel 7 merupakan kumpulan tanggapan responden mengenai Lingkungan Kerja yang ada pada Kantor Administrator Pelabuhan Makassar menunjukkan bahwa karyawan jawaban sangat puas dengan jumlah responden 40 orang atau $64,5 \%$, jawaban puas jumlah responden 17 orang atau $27,4 \%$, jawaban cukup puas jumlah responden 5 orang atau 8,1\%, jawaban tidak puas jumlah responden 0 atau $0 \%$, sedangkan jawaban sangat tidak puas 0 atau0\%. Berarti Lingkunagan Kerja dapat meningkatkan semangat dan kegairahan kerja mereka.

Tabel 8. Klasifikasi responden berdasarkan Fasilitas dan Sarana Kerja Karyawan pada Kantor Administrator Pelabuhan Makassar

\begin{tabular}{ccc}
\hline $\begin{array}{c}\text { Jawaban } \\
\text { Responden }\end{array}$ & $\begin{array}{c}\text { Jumlah } \\
\text { Responden }\end{array}$ & Persentase (\%) \\
\hline Sangat Puas & 34 & 54,8 \\
Puas & 20 & 32,3 \\
Cukup Puas & 5 & 8,1 \\
Tidak Puas & 3 & 4,8 \\
Sangat Tidak Puas & - & - \\
Jumlah & 62 & 100 \\
\hline
\end{tabular}

Sumber: Hasil pengolahan data 2021

Dari tabel 8 dapat dilihat bahwa Fasiliyas dan Sarana Kerja memberi pengaruh pada peningkatan terhadap semangat dan kegairahan kerja karyawan pada Kantor Administrator Pelabyhan Makassar, yaitu dari jawaban sangat puas jumlah responden 34 orang atau 54,8\%, jawaban puas jumlah responden 20 orang atau 32,3\%, jawaban cukup puas jumlah responden 5 orang atau 8,1\%, jawaban tidak puas jumlah responden 3 orang atau 4,8\%, sedangkan jawaban sangat tidak puas jumlah responden 0 orang atau $0 \%$.

Tabel 9. Klasifikasi responden berdasarkan Tingkat Penghasilan karyawan pada Kantor Administrator Pelabuhan Makassar

\begin{tabular}{ccc}
\hline $\begin{array}{c}\text { Jawaban } \\
\text { Responden }\end{array}$ & $\begin{array}{c}\text { Jumlah } \\
\text { Responden }\end{array}$ & Persentase (\%) \\
\hline Sangat Puas & 30 & 48,4 \\
Puas & 25 & 40,3 \\
Cukup Puas & 5 & 8,1 \\
Tidak Puas & 2 & 3,2 \\
Sangat Tidak Puas & - & - \\
Jumlah & 62 & 100 \\
\hline
\end{tabular}

Sumber: Hasil pengolahan data 2021

Dari tabel 9 diatas dapat dilihat bahwa dari hasil 62 kuisioner tang diedarkan pada responden karyawan pada Kantor Administrator Pelabuhan Makassar berdasarkan Tingkat Penghasilan, yaitu dari jawaban sangat puas jumlah responden 30 orang atau 48,4\%, jawaban puas jumlah rseponden 25 orang atau 40,3\%, jawaban puas jumlah responden 5 orang atau 8,1\%, jawaban tidak puas jumlah responden 2 orang atau 3,2\%, dan jawaban sangat tidak puas jumlah responden 0 atau 0\%. Dengan demikian Tingkat Penghasilan juga berpengaruh terhadap semangat dan kegairahan kerja karyawan.

Tabel 10. Klasifikasi responden berdasarkan Keamanan dan Keselamatan Karyawan pada Kantor Administrator Pelabuhan Makassar

\begin{tabular}{ccc}
\hline $\begin{array}{c}\text { Jawaban } \\
\text { Responden }\end{array}$ & $\begin{array}{c}\text { Jumlah } \\
\text { Responden }\end{array}$ & Persentase (\%) \\
\hline Sangat Puas & 32 & 51,6 \\
Puas & 25 & 40,3 \\
Cukup Puas & 5 & 8,1 \\
\hline
\end{tabular}




\begin{tabular}{ccc}
\hline Tidak Puas & - & - \\
Sangat Tidak Puas & - & - \\
Jumlah & 62 & 100 \\
\hline & Sumber: Hasil pengolahan data 2021
\end{tabular}

Dari tabel 10 diatas dapat dilihat bahwa dari hasil 62 kuisioner yang diedarkan pada responden karyawan pada Kantor Administrator Pelabuhan Makassar berdasarkan Keamanan dan Keselamatan kerja yaitu dari jawaban sangat puas jumlah responden 32 orang atau 51,6\%, jawaban puas jumlah responden 25 orang atau40,3\%, jawaban cukup puas jumlah responden 5 orang atau $8,1 \%$, jawaban tidak puas jumlah responden 0 atau $0 \%$, dan jawaban sangat tidak puas jumlah responden 9 atau $0 \%$. Hal ini berarti bahwa karyawan merasa puas sehingga mereka dapat bekerja dalam perasaan aman dan keselamatan juga di perhatikan oleh perusahaan.

Tabel 11. Klasifikasi responden berdasarkan Hubungan karyawan dengan Pimpinan Pada Kantor Administrator Pelabuhan Makassar

\begin{tabular}{ccc}
\hline Umur (thn) & Jumlah Responden & Presentase (\%) \\
\hline Sangat Puas & 29 & 46,7 \\
Puas & 23 & 37,1 \\
Cukup Puas & 6 & 9,7 \\
Tidak Puas & 4 & 6,5 \\
Sangat Tidak Puas & - & - \\
Jumlah & 62 & 100 \\
\hline
\end{tabular}

Sumber: Hasil pengolahan data 2021

Dari tabel 11 diatas memperlihatkan bahwa karyawan sangat puas dengan hubungan yang tercipta dalam perusahaan, adanya hubungan yang harmonis antara karyawan dan pimpinan turut mempengaruhi karyawan dalam bekerja.

Dari hasil kuisioner keseluruhan memperlihatkan bahwa faktor-faktor yang mempengaruhi semangat dan kegairahan kerja karyawan adalah faktor kondisi kerja yaitu: fasilitas dan sarana kerja, lingkunagan kerja, tingkat penghasilan, keamanan dan keselamatan kerja, hubungan kerja karyawan dengan pimpinan. Hal ini berarti hipotesis diajukan penulis terbukti bahwa lingkungan kerja turut mempengaruhi semangat dan kegairahan kerja karyawam pada Kantor Administrator Pelabuhan Makassar.

Penjelasan dari tabel 12 sebagai berikut:

1. Dari ke 5 pengaruh diatas dapat dilihat pada Lingkungan Kerja, jawaban responden dengan "Puas" ada 57 orang atau 20,7\%, jawaban responden dengan "Cukup Puas" ada 5 orang atau $19,2 \%$, dan jawaban responden dengan "Tidak Puas" 0 atau $0 \%$.

2. Dari ke 5 pengaruh diatas dapat dilihat pada Fasilitas dan Sarana kerja, jawaban responden dengan "Puas" ada 54 orang 19,9\%, jawaban responden dengan "Cukup Puas" ada5 orang atau 19,2\%, dan jawaban responden dengan "Tidak Puas" ada 3 orang atau $33,3 \%$.

3. Dari ke 5 pengaruh diatas dapat dilihat oada Tingkat Penghasilan jawaban responden dengan "Puas" ada 55 orang atau 20\%, jawaban responden dengan "cukup Puas" ada5 orang atau 19,2\%, dan jawaban responden dengan "Tidak Puas" 2 orang atau 22,2\%.

4. Dari ke 5 pengaruh diatas dapat dilihat pada Keamanan dan Keselamtan Kerja, jawaban responden dengan "Puas" ada 57 orang atau 20,7\%, jawaban responden dengan "Cukup Puas" ada 5 orang atau 19,2\%, dan jawaban responden dengan "Tidak Puas" 0 atau $0 \%$.

5. Dari ke 5 pengaruh diatas dapat dilihat pada Hubungan Karyawan dengan Pimpinan, jawaban responden dengan "puas" ada 52 orang atau 18,9\%, jawaban responden dengan "Cukup Puas" ada 6 orang atau 23,2\% dan jawaban responden dengan "Tidak Puas" 4 atau $44,4 \%$.

Dari jumlah ke 5 pengaruh lingkungan kerja terhadap semangat dan kegairahan kerja, jawaban dengan "Puas" ada 275 atau 99,9\%, "Cukup Puas" ada 26 atau 100\%, dan "Tidak Puas" 
ada 9 atau 99,9\% dan untuk Rata-rata total keseluruhan pada jawaban "Puas" dengan Rata-rata 55\% atau 19,98\%, jawaban "Cukup Puas" dengan Rata-rata 5,2\% atau 20\%, dan jawaban "Tidak Puas" dengan Rata-rata 1,8\% atau 19,9\%.

Tabel 12. Rekapitulasi Pengaruh Lingkungan Kerja

\begin{tabular}{ccccccc}
\hline \multirow{2}{*}{ Faktor Kondisi } & \multicolumn{2}{c}{$\mathbf{1}$} & \multicolumn{2}{c}{$\mathbf{2}$} & $\mathbf{3}$ \\
& Jml & $\mathbf{\%}$ & Jml & $\mathbf{\%}$ & Jml & $\mathbf{\%}$ \\
\hline Lingkungan Kerja & 57 & 20.7 & 5 & 19,2 & 0 & 0 \\
Fasilitas dan Sarana Kerja & 54 & 19,6 & 5 & 19,2 & 3 & 33,3 \\
Tingkat Penghasilan & 55 & 20 & 5 & 19,2 & 2 & 22,2 \\
Keamanan dan Keselamatan Kerja & 57 & 20,7 & 5 & 19,2 & 0 & 0 \\
Hub. Karyawan dengan Pimpinan & 52 & 18,9 & 6 & 23,2 & 4 & 44,4 \\
Total & 275 & 99,9 & 26 & 100 & 9 & 99,9 \\
Rata-rata & 55 & 19,98 & 5,2 & 20 & 1,8 & 19,98 \\
\hline
\end{tabular}

Sumber: Hasil pengolahan data 2021

Keterangan:

1. Puas

2. Cukup Puas

3. Tidak Puas

\section{KESIMPULAN}

Berdasarkan kesimpulan diatas dari kuisioner yang diedarkan pada responden karyawan Kantor Administrator Pelabuhan Makassar menunjukkan bahwa sebagian besar responden merasa setuju atau puas bahwa Lingkungan Kerja berpengaruh positif terhadap Semangat dan Kegairahan Kerja karyawan pada Kantor Administrator Pelabuhan Makassar. Ini terlihat adanya jawaban responden sangat puas sebanyak 64,5\%.

Untuk meningkatkan mutu pelayanan dan pelaksanaan tugas-tugas kantor maka setiap karyawan hendaknya menjadi karyawan yang memiliki disiplin yang tinggi dan bertanggung jawqab dlam menyelesaikan pekerjaannya dan perlu meningkatkan kerja sama yang lebih erat antara sesama karyawan maupun antara pimpinan dengan karyawan sehingga para karyawan merasa diperhatikan. Dan perlunya penempatan personil yang sesuai dengan kemampuan, keterampilan serta pendidikan yang dimiliki sedangkan suasana kerja yang rutin kadang menimbulkan kebosanan dan ketegangan kerja bagi karyawan.

\section{DAFTAR PUSTAKA}

Abdi, S., (2018). Fakultas Social Sains "Pengaruh Promosi Jabatan Dan Lingkungan Kerja Terhadap Semangat Kerja Pegawai Dilingkungan Universitas Pembangunan Pancabudi Medan". Universitas Pembangunan Panca Budi.

Basir, B. (1998). Manajemen Sumber Daya Manusia, Penerbit Bumi Aksara, Jakarta.

Candra, P. M. \& Satria, T. (2018). Program Studi Magister Manajemen Universitas Muhammadiya Sumatra Utara Medan."Pengaruh Stress Kerja, Motivasi Kerja Dan Lingkungan Kerja Terhadap Semangat Kerja Pegawai".

Eko, M., \& Sri, L. R. (2018). "Pengaruh Lingkungan Kerja, Insentif, Komunikasi Dan Senioritas Terhadap Semangat Kerja Karyawan". Program Studi Magister Manajemen Pascasarjana Universitas Riau Kepulauan.

Ferli, E. (2017). Jurnal Ekonomi Dan Bisnis”Pengaruh Lingkungan Kerja Terhadap Semangat Kerja Karyawan Stie Nasional Banjarmasin."

Handoko, D. \& Hani, T. (2000). Manajemen Personalia dan Sumber Daya Manusia, Edisi kedua, Cetakan Keenam Belas, BPPE, Yogyakarta. 
Hasibuan, M. S. P. Drs. (2006). Manajemen Sumber Daya Manusia, Edisis Revisi, Penerbit Bumi Aksara.

Jaya, I. G. M. K., Sudiya, I. G. A., \& Sudharma, I. N., (2017). Fakultas Ekonomi Dan Bisnis “Pengaruh Lingkungan Kerja Dan Motivasi Serta Kompensasi Terhadap Semangat Kerja Pegawai Dinas Kesehatan Kabupaten Tabanan." Universitas Udayana Bali.

Nova, S., \& Vina, L. (2019) “Pengaruh Lingkungan Kerja Terhadap Semangat Kerja Guru Pada SMK NEGRI I UKUI, Sekolah Tinggi Ilmu Ekonomi Riau”, 167-176.

Noor, A. (2015). Program Studi Ilmu Administrasi Negara "Pengaruh Lingkungan Kerja Terhadap Semangat Kerja Pegawai Dikantor Kelurahaan Air Putih Samarinda."

Nitisemito, A. S. (1997). Manajemen Personalia (Manajemen Sumber Daya Manusia), Edisi Revisi, Ghalia Indonesia, Jakarta.

Panca, D. P. (2017). Sosiologi Ilmu Social Dan Ilmu Politik "Pengaruh Lingkungan Kerja Terhadap Semangat Kerja Karyawan Pada CV. Jaya Karya Pekanbaru".

Panggabean, S., \& Mutiara. M. E. Dr. (2004). Manajemen Sumber Daya Manusia, Cetakan Kedua, Penerbit Ghalia Indonesia.

Ranu, P., Heidrachman, \& Husnan, S. (1999). Manajemen Personalia, Edisi Keempat, BPFE, Yogyakarta.

Sinar, H. D., Timotios, D., Progresif, B. (2021) "Pengaruh Lingkungan Kerjaterhadap Semangat Kerja Pegawai Yang Dimediasi Oleh Kepemimpinan Studi Pada Dinas Perpustakaan Kabupaten Nias Selatan."103-114.

Sedarmayanti, (2001). Manajemen Sumber Daya Manusia dan Produktifitas Kerja, Mandar Maju, Bandung.

Try, S. H. Z, (2018) Study Of Business Administration Fakultas Social Dan Politik Rian Universitas. "Pengaruh Lingkungan Kerja Dan Kesejahteraan Karyawan Terhadap Semangat Kerja Karyawan Studi Pada Kantor Pusat Pt Perkebunan Nusantara V Pekanbaru)." 